\title{
84 顎下腺、煩部粘膜の悪性リンバ腫について
}

\author{
松井隆史 - 斎藤等 - 佐藤文彥 \\ 山道至・水越治
}

（京府医大耳鼻科）

蕷下腺、煩部粘膜より発生した曹性 リンパ腫は 比較的稀らしく、私共の教室では、昭和 32 年から 昭和 51 年までの 19 年間に 7 例経験した。このうち 追跡不明の 1 例を除く 6 例について検討した。 類下腺部のものは stage Iが 2 例、 stage II が 1 例で、煩部粘膜由来のものは stage I 、II、N が それぞれ 1例づつの 3 例であった。初診時年令は 1 才代が 1 例、 50 才代が 1 例、60才代が 3 例、70 才代が1例でいずれも男子である。初発症状から 初猃までの期間は、 stage I が 3 例で 1 ケ月、2 ケ月、5 ケ月であり、 stage III 2 例で 1 ケ月、 3 ケ月であった。 stage $\mathrm{N}$ の1例は 1 ケ月で受診 している。これら6症例はいずれも stage III、N に移行したのち死亡しているが、 stage I、II か ら s tage III、Nに移行するまでの期間をみると、 stage Iの 3 例は、1 ケ月半、 1 年 9 ケ月、 5 ケ 月であり、stage II の 2 例は、 2 ケ月および 4 年 5 ケ月であった。䞄下腺、煩部粘膜部は初診時に 悪性リン八゚腫と診断することは踓かしい。本 6 症 例の確定診断を得た過程は、試切が 2 例、手術施 行例が 4 例で、手術の内容は、額下腺摘出が 1 例、 煩部菌跑部腫㻛摘出が 1 例、頻下腺全摘出、頸部 郭清術が 1 例であった。治療法別に生存期間をみ ると、放射線十ステロイド剤の併用は stage I の 1 例のみで、生存期間は 7 ケ月で、放射線十局所 動注は stage II の症例が 1 例で、7 7 月の生存、 手術十放射線は stage Iの 1 例で、2 年 1 ケ月の 生存、手術十放射線 十化学療法は 3 例で、stage I が 4.5 ケ月、 stage III が 5 ケ月、 stage $\mathrm{N}$ が10 ケ月 の生存期間であった。この結果より、手術的療法
よりも、非手術的療法の方が延命効果があり、ま た stage が若いと言えども必ずしも生存期間は長 くはない。䫟下腺部、煩部粘膜より生ずる悪性り ンパ腫の予後が極めて悪いのは、一つには、部位 的特殊性のために、先行した手術的療法後の病理 組織により診断が確定することが多いため、たと え stage I であっても stage III、Nに移行しやす いためでもあろうし、また一方、頻下腺のリンパ 腫と思われても、周囲のリンパ節原発のいわゆる Nodal の悪性リンパ腫が多いためと考えられる。 いずれにしても今後この領域の悪性リンパ腫は、 診断がつき次第、放射線治療よりも徹底した化学 療法を早期に行うことが寛解導入への可能性が高 いのではないかと考える。

追加

斎藤（京府医大）

全身への進展 (全身型) 状態の判定には限界が あり、現在ではリンパ管造影 ZGa シンチの二つの みで、私の所では診断している。

唾液腺の悪性リンパ腫は、extranodal 性のも のと、いわゆる nodal 性のものとがあり、予後の 悪いものと比較的良いものとわかれるのではない か。全身化学療法が重要である。 